\title{
Sustainable infrastructure delivery in Nigeria: implementation of the analytic network process for contractor selection
}

\author{
Oluwunmi Arowosafe ${ }^{1}$, Olufolahan Oduyemi ${ }^{2, *}$, Boris Ceranic ${ }^{1}$, and Angela Dean ${ }^{1}$ \\ ${ }^{1}$ College of Engineering and Technology, University of Derby, Derby, UK \\ ${ }^{2}$ College of Engineering and Technology, Southeast Missouri State University, Missouri, USA
}

Received: 26 March 2018 / Accepted: 20 June 2018

\begin{abstract}
Purpose: This paper presents research findings that involve the use of analytic network process (ANP) to select contractors for build-operate-transfer (BOT) infrastructure in Nigeria. To deliver sustainable infrastructure (SI), a responsive methodology is required for contractors' selection process, which combines judgement and data for an effective outcomes prediction. Design/methodology/approach: Theoretically grounded on a system theory, sustainable infrastructure delivery (SID) model has been developed in this study. At the deductive phase of the model is the integration of the ANP (a multicriteria decision-making technique) for data synthesis. To obtain decision criteria, 55 sustainability indicators for contractor selection were identified from the literature review. The criteria were first developed to a web-based questionnaire where respondents were requested to rank the importance of the criteria towards selecting contractors that deliver SI, using Likert scale of $1-5$ (where " 5 " is very important and " 1 " is not important). The results were analysed using factor analysis. Data were further reduced to 16 variables after multicollinearity issues in the data set had been resolved. To weigh the relative importance of the 16 criteria among contractors, ANP methodology was adopted for the second-round questionnaire. The seven-man decision panel that completed the pairwise comparison survey was selected through a purposeful sampling technique. The final survey results were synthesised by Super Decisions (computer package that implements ANP) trial version to rank contractors' options and predict outcomes. Findings/results: Sensitivity analysis of the research findings reveals that the 16 criteria have differential comparative advantages, which requires critical judgement during contractor's pre-evaluation process. Although the overall priorities rank multinational construction corporations (MCC) higher than local construction companies (LCC), MCC are not absolute to deliver SI. LCC are sensitive to some key criteria that are critical to the actualisation SI agenda. Originality/value: This study fills the gap in the knowledge of SID in Nigeria. The study theoretically suggests a framework to harmonise sustainability indicators in contractor selection. The findings further provide feedbacks that can be incorporated to Government's Ministries, Department and Agencies (MDAs) procurement policy to promote SID.
\end{abstract}

Keywords: sustainable infrastructure / poverty / analytic network process / system / build-operate-transfer / Nigeria

\section{Introduction}

Sustainable infrastructure delivery (SID) is a broad concept and it embraces the design, building and operation of constructed facilities in such a way that promote sustainable development (SD). Due to the impacts of contemporary issues on construction industry in developing countries (DC) [1,2], the United Nations (UN) has identified the need for global partnership for development as a strive towards social development [1]. At the top of the millennium declarations by the UN, in September 2000,

\footnotetext{
* e-mail: olufolahanoduyemi@yahoo.co.uk
}

was the eradication of extreme poverty and hunger in DC. According to reference [3], "poverty connotes a condition of human deprivation or denial with respect to the basic necessities of life: food, shelter and clothing." Another school of thought describes poverty as a development problem [4]. This is the case of omission of essential elements during a development programme.

Despite numerous studies on construction activities in DC $[5,6]$, conceptual framework for the implementation of social procurement is not substantial. The ideology of social procurement is the use of procurement to foster social benefits and values for the communities beyond the purchase and consumption of goods and services. Construction industry is globally recognised as a sector of the 
economy that promotes social development through procurement programmes [5]. Meanwhile, Ofori [6] argued that construction activities in DC are merely shopping list where coordinated series of planned activities, which optimise systemic value delivery, are missing. The worldviews on poverty by $[3,4]$ could well depict the level of social progress [3,7,8] and challenges of SID in Nigeria [9].

While global partnership for development is advocated for poverty eradication, Moyo [4] rebuffed the claim that poverty is endemic to DC; rather it is embroiled in economic engagement between developed and developing worlds. Poverty in Nigeria, and DC at large, could be discussed in its richness, based on its drivers. Moyo [4] and Ofori [10] believed that development problem is the bedrock of poverty in DC. While the solution to poverty eradication in DC relies upon internal development programmes and global collaboration, capitalism has urged economic and political influences in procurement decision with consequential impacts on social values. Multinationals, as a case for construction sector, could exercise their political strength and economic leverage to cripple economic, social, community and technical sustainability of the host nation for monetary gains [11]. The grant of the right of first refusal to multinational construction corporation (MCC) in Nigeria [11], for instance, sanctions the absolute clout being exercised by the multinationals during contract formation in DC. Hence, responsive poverty eradication goes beyond a mere global partnership for development. There is a need for coordinated activities that can measure and review social progress and capability building in infrastructure delivery.

Despite growing knowledge of SD in Nigeria [12,13], SID has not been extensively explored. The main aim of the paper is to develop a framework for contractor selection that promotes SID in BOT procurement strategy. The rest of this paper is organised as follows: Section 2 discusses literature findings on the related concepts of SID. Section 3 presents research methodology with the highlights rationale for research design and applied research methods. Section 4 discusses research results.

\section{Previous related work}

After in-depth literature review, particularly in the knowledge areas of construction industry, SD, innovative procurement strategy and multicriteria decision-making technique, which are considered significant to the subject area, previous related work is structured under five subsections: (1) construction industry and social challenges, (2) social value and economic reform programmes, (3) build-operate-transfer strategy, (4) sustainable infrastructure and contractor selection and (5) analytic network process (ANP), as a multicriteria decisionmaking technique.

\subsection{Construction industry and social challenges in Nigeria}

Construction sector is a fundamental economic sector and it is globally acknowledged as a catalyst for SD $[1,5]$. The sector promotes positive societal changes due to its systemic effects on broader economic sectors $[1,5]$ through demand for material and human resources. Available data concede to the overwhelming contribution of construction activities to gross domestic product (GDP) and human development in European Union [14]. Egan report [14] revealed that construction sector represents $40 \%$ of the capital projects in the UK, which account for $7 \%$ of GDP. The significance of construction activities is not peculiar to developed countries alone. An average of $5 \%$ of the annual GDP in Nigeria is generated from construction sector [15]. Much recently, studies have attributed $13.4 \%$ of global GDP to construction industry and the index is expected to reach $14.6 \%$ by 2020 [5]. With the growing demand for constructed facilities, about $50 \%$ of the Nigerian government expenditures is budgeted on construction projects [15]. Yet, it is estimated that around $\$ 12-15 \mathrm{~b}$ investment would be required annually for the next 10 years to solve infrastructure problems in Nigeria [9]. These evidences further substantiate the ability of the sector as a driver for social progress through demand for material and human resources. Therefore, deficiencies in the performance of construction sector will have huge impacts on national wealth creation and development.

Wistfully, socio challenges in Nigeria have remained almost consistent over the past decades $[3,7,8,11,16]$. There are millions of populations that are languishing in extreme hunger and abject poverty $[3,7,8]$. Notwithstanding an average growth rate of $6.2 \%$ in economy between 2002 and 2011 [8], over $70 \%$ of the Nigerian population are estimated to live on an average of a dollar $(\$)$ or less per day [3]. With a GDP second only to South Africa in Africa, Nigeria was rated absurdly low in key social indicators, which are per capita income, immunisation, improved sanitation facilities and mortality rate, when compared [17]. The findings were further validated by the SD report of 2012 [8], showing the disparity between the GDP and poverty trend in Nigeria. While the economy had grown at an average of $6.2 \%$ between 2002 and 2011, the apparent disconnect between economic growth and human development was obvious. Using 1980 as the basepoint for poverty trend, by 2010, it had surged by $50 \%$ above $25 \%$. Unemployment level has risen from $3.8 \%$ in 2003 to a whopping $23.9 \%$ in 2012 . The class of people that are most affected are aged between 18 and 35 [7]. It is no gainsaying to conclude that extreme poverty and hunger is the driver for unhealthy macroeconomic environment in Nigeria, characterised with high rate of crime and related social vices $[3,7]$.

\subsection{Social value and economic reform programmes in Nigeria}

Globally, social value is becoming an increasingly important index of value for money in public domain. Contractors are no longer evaluated only on their proficiency to deliver quality infrastructure; they must demonstrate how the delivery process will bolster social progress. As part of the social development agenda, in 2013, Social value Act was introduced in the UK. The act regulates government agencies to weigh $10-20 \%$ of tender on social value. The applied social value metric in infrastructure procurement 
includes the percentage of locals that would benefit from apprentices and eventually gain full employment with the prospective contractors [6].

Following years of economic stagnation caused by military rule and poor economic management, the Nigeria government embarked on comprehensive economic reform programme during the fourth democratic rule from 1999, with the introduction of the National Economic Empowerment and Development Strategy (NEEDS) [3,17]. The scopes of NEEDS were as follows: (1) to improve the macroeconomic environment, (2) to pursue structural reforms, (3) to strengthen public expenditure management and (4) to implement institutional and governance reforms. Okonjo-Iweala and Osafo-Kwaako [17] highlight that the central objective of the government macroeconomic reform was to stabilise the economy, to improve budgetary planning and execution and to provide a platform for sustained economic diversification and nonoil growth.

Weighing the correlation between unemployment and SD, government further enacted the Nigerian Local Content (NLC) Act in 2010 [18]. The act is aimed at a systematic development of capacity and capabilities through a deliberate utilisation of local human, material resources and services in the key economic sectors [18]. Meanwhile, monetary budget remains a major challenge faced by the ministries, department and agencies (MDAs) in public infrastructure delivery. In a quest for private funding for infrastructure, Infrastructure Concession Regulatory Commission (ICRC) was established under ICRC Act, in 2005. The principal goal of ICRC is to attract construction contractors that can build and finance capital projects for MDAs [19]. The agency is also responsible for the development and implementation of Public-Private Partnership (PPP) framework for infrastructure procurement.

\subsection{Build-operate-transfer procurement strategy}

Build-operate-transfer (BOT) model is often referred to as a core PPP due to a substantial amount of risks being transferred to the private sector $[9,19,20]$. Myths of BOT includes the reliance on private funding as a debt relief for MDAs, transfer of project risks to the private sector, empowerment of locals through technology transfer and training programmes. BOT strategy involves the granting of franchise or concession by the public or private sector to private entity, referred to as the concessionaire [20] for the procurement of infrastructure. Concessionaire, otherwise known as project consortium or special purpose vehicle (SPV), is a group of private investors. SPV takes the responsibility for the project finance, construction, operation and maintenance of constructed facilities over concession period. During the concessionary period, funds raised from services charges are spent towards operational and maintenance cost and recoup of invested capital by private entity. The project is then returned to the client at the end of the concession period at no cost. Though BOT has gained global recognition back to nineteenth century [20], it is at the experimental stage in Nigeria. The first set of concession-based projects was commissioned around 2006 [9].
With the scope of BOT spanning to all modes of transportation, power projects, telecommunication, water supply, solid waste management, housing, education, agriculture and health facilities, it buttresses the significance of construction sector in a national economic system. It also presents a special case for the integration of social values in the selection criteria for contractors. To date, public infrastructure procurement through BOT, in Nigeria, has reached an unprecedented level. In contrast, social development has not been significantly enhanced. Patil et al. [21] observed that, in DC, PPP promote unequal development and social marginalisation, due to uncoordinated developmental programmes. Though perpetual poverty in Africa has been linked to global capitalism and free trade [4], local contractors are characterised with low quality of workmanship, lack of innovative approach and technology, inability to attract credit facilities and lack of innovative construction methods $[2,11]$.

Nevertheless, concerns have been raised on the integration of the effectiveness of the myths of BOT in contractor selection policy in Nigeria. Though present regulation on PPP strategies encourage the implementation of life cycle costing method for the evaluation of the long-term project costs [12], only economic performances are often evaluated. Arowosafe et al. [22] had contended that the evaluation of project's "intangible costs" is often obscured during preconstruction cost evaluation.

\subsection{Sustainable infrastructure and contractor selection}

The discourse on SD is often underpinned by the evaluation of the human activities on environment, either material consumption or implication of material use and processing on the environment. The first global UN summit on SD was in 1972, following the unprecedented post-war industrialisation and concerns on the consumption of natural resources and the impacts on basic environmental limits. While various measures have been implemented globally to manage SD, the wide acceptance of the 1987 Brundland report on SD as a development that meets the needs of the present without compromising the ability of future generations to meet their own needs has a profound influence on the modern-day interpretation of the concept of SD in construction industry. This may be associated with the rationale of the environmental issues being commonly used for sustainability indicators in scholarly research [13] (Ngowi 1998).

While both developed and developing countries strive for SD, the level of development differs between geographical locations. Du-Plessis [1] summarised SD as the management of the relationship between human needs and their environment as not to exceed critical environmental limits. Du-Plessis [1] discussed factor that determine the level of the relationship between humans and their environment under two main factors that constitute a value system of a society. They are (1) the interpretation of "quality of life" in a society and (2) the choices made in terms of interrelated systems in a society - such related systems in the society as technological, political and economic system. 


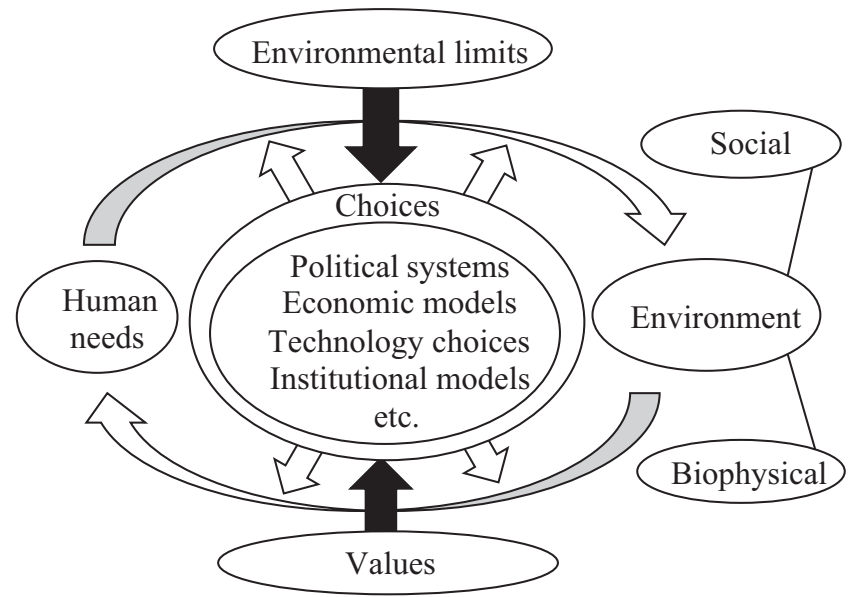

Fig. 1. A relational model of SD. Source: Du-Plessis [1].

From Figure 1, it can be deduced that SD is systemic in nature and contextual. The established political system and other related societal models (economic, technology, etc.) dictate the best decision arrived upon. It further concludes on differential SD between developed and developing countries.

Over the past decades, various programmes have been initiated to foster the development of construction industry in Nigeria, and DC at large had failed [6]. Despite decades of research in built environment, the problems have remained unsolved. Dated back to 1998, a meeting CIB Task Group 29 (TG 29) was held in Tanzania and the goal was to formulate indicators for the capture of progress of the industry in developing countries [6]. More recently, needs for the improvement of socio-economic development in DC has attracted international attentions. The International Council for Research for Innovation in Building and Construction (CIB) collaborated with UN and developed "Agenda 21" for sustainable construction in DC (A21SCDC) [1].

Though problems of construction in DC include material and technology problems, financial problems, skilled human resources shortage, legal issue and polities, marketing and productivity problems [2], they are systemic and go beyond social and economic issues. As a guide for best practice, British Standard (BS 8903: 2010) itemised key sustainability issues (see Tab. 1) that can be evaluated during decision-making process on sustainable procurement.

To date, numerous attempts have been made by researchers to elucidate selection criteria for contractors (see [23-27], Wang et al. 2013). While selection criteria are well developed, there is consensus neither on the number of criteria nor on the general theory that underlay the selected criteria. In general, frailty in contractor selection practice are lack of universal approach, long-term confidentiality to prequalification outcomes, reliance on cost-based decisionmaking and subjectivity of the process [23].

Common selection criteria that are consistently applied among clients include past-experience, resources, current work load, past client-contractor relationship, safety performance, tender price, financial capability and past performance [24,27]. In general, lack of benchmark for contractor selection in public sector has been attributed to the popularity of the application of conventional selection criteria among public clients [25,26]. Traditionally, contractor selection is demand driven [10]. To delineate benchmark criteria for contractor selection, common expressions that have evolved among researchers were reviewed. Walraven and de Vries [10] advocate for valuedriven contractor selection. Palaneeswaran et al. [25] explore how public client can optimise value for money through best value-focused contractor selection. Wong et al. [27] made a case for the abolition of lowest price practice and the embracement of project-specific criteria during contractor prequalification evaluation.

Though Palaneeswaran et al. [25] advocated for best value in contractor selection, they consented to the ambiguity in best value concept, and the interpretation of value. For instance, in the context of usage of value by Wong et al. [27], selection criteria are limited to conventional approach. Walraven and de Vries [10] and Palaneeswaran et al. [25] emphasised on importance of a shift from demand driven to value driven. Though public client enjoys less freedom in contractor selection [25], the approach explores cost elements of the contractor selection beyond tangibles. Construction cost can be classified as actual cost and opportunity costs [22]. Actual costs are tangibles and they can easily be anticipated. Actual cost is measured based on cost of factors of production, overheads and profit margin for contractor. Opportunity cost considers overall impacts of alternative options during contractors' selection. They are not easily quantifiable, but their impacts can be forecasted to long terms.

While different potential attributes of sustainable procurement have been identified, decision making would become more complex and challenging due to dependency among various decision factors. Hypothetically, with the pluralisation of construction client in BOT strategy, decision makers (DM) are faced with the huddle of trade-off between stakeholders' stakes, which are often the combination of tangibles and intangibles.

\subsection{Background of ANP}

As highlighted earlier, there is no consensus selection criteria that support SID in the literature. BOT, as a procurement strategy, presents a case for conflicting interests among construction stakeholders due to the pluralistic nature of construction client. ANP is a decisionfinding method that can model a complex decision problem. The technique is a powerful synthesis methodology for combining judgement and data to effectively rank options and predict outcomes. The uniqueness of the technique is the shift from "unidirectional" to "close-loop" approach in the structure of a problematic decision. As such, it resolves the setback in commonly applied unidirectional mathematical approach to solve real-life messy decisions.

Presented in Table 2 is the summary of studies in the literature that demonstrate the efficiency and effectiveness of ANP in solving complex decision problems. 
Table 1. Examples of key sustainability issues.

\begin{tabular}{|c|c|c|}
\hline Environmental issues & Social issues & Economic issues \\
\hline $\begin{array}{l}\text { Emissions to air (e.g. greenhouse } \\
\text { gases, such as carbon } \\
\text { dioxide and other pollutants) }\end{array}$ & $\begin{array}{l}\text { Encouraging a diverse base of } \\
\text { suppliers (e.g. minority or } \\
\text { underrepresented suppliers) }\end{array}$ & $\begin{array}{l}\text { Job creation (e.g. green } \\
\text { technologies, creating markets for } \\
\text { recycled products, back to work } \\
\text { schemes) }\end{array}$ \\
\hline $\begin{array}{l}\text { Releases to water (e.g. chemical } \\
\text { pollution of water courses) }\end{array}$ & $\begin{array}{l}\text { Promoting fair employment } \\
\text { practices (e.g. fair wages, } \\
\text { workforce equality, diversity, } \\
\text { avoidance of bonded labour) }\end{array}$ & $\begin{array}{l}\text { Understanding whole life costs to } \\
\text { achieve value for money }\end{array}$ \\
\hline $\begin{array}{l}\text { Releases to land (e.g. chemical } \\
\text { fertilizers) }\end{array}$ & $\begin{array}{l}\text { Promoting workforce welfare (e.g. } \\
\text { health and safety, trade union } \\
\text { membership) }\end{array}$ & $\begin{array}{l}\text { Supporting small and medium } \\
\text { enterprises (SMEs) (e.g. } \\
\text { facilitating opportunities for small } \\
\text { businesses) }\end{array}$ \\
\hline $\begin{array}{l}\text { Use of raw materials and natural } \\
\text { resources } \\
\text { (e.g. sustainable forestry, } \\
\text { biodiversity) }\end{array}$ & $\begin{array}{l}\text { Enabling training opportunities } \\
\text { and skills development (e.g. } \\
\text { apprenticeships) }\end{array}$ & $\begin{array}{l}\text { Reducing entry barriers (e.g. } \\
\text { facilitating open competition) }\end{array}$ \\
\hline $\begin{array}{l}\text { Use of energy (e.g. energy } \\
\text { efficiency, renewables) }\end{array}$ & $\begin{array}{l}\text { Community benefits (e.g. } \\
\text { supporting community groups, } \\
\text { volunteering) }\end{array}$ & $\begin{array}{l}\text { Ensuring operating business } \\
\text { remains a viable operation able to } \\
\text { provide employment }\end{array}$ \\
\hline $\begin{array}{l}\text { Energy emitted (e.g. heat, } \\
\text { radiation, vibration, noise) }\end{array}$ & $\begin{array}{l}\text { Fair trade and ethical sourcing } \\
\text { practices (e.g. fair pricing } \\
\text { policies) }\end{array}$ & $\begin{array}{l}\text { Ensuring suppliers' agreements } \\
\text { are at fair and viable margins }\end{array}$ \\
\hline $\begin{array}{l}\text { Waste and by-products (e.g. } \\
\text { recycling and waste prevention) }\end{array}$ & & $\begin{array}{l}\text { Ensuring business continuity (e.g. } \\
\text { supply chain resilience) }\end{array}$ \\
\hline
\end{tabular}

Source: BS 8903:2010.

Table 2. Literature review on the application of ANP.

\begin{tabular}{ll}
\hline Project & Author(s) \\
\hline Election of green marketable products & Neubert (2015) \\
Integrating three-dimensional sustainability in distribution centre selection & Neumüller et al. (2015) \\
Selection of solar-thermal power plant investment projects & Aragones-Beltra et al. (2014) \\
A support tool for policy making on renewable energy development & Cannemi et al. (2014) \\
Ranking of critical success factors of waterfront development & Lee et al (2013) \\
Assessment of best available techniques & Giner-Santonja et al. (2012) \\
Sitting of a municipal solid waste plant in the metropolitan area & Aragones-Beltra et al. (2010) \\
Selection of a televised sports-casters for Olympic Games & Chang (2009) \\
Risks assessment in commercial real estate development & Khumpaisal (2009) \\
Selection of lean manufacturing systems & Kodali (2009) \\
Vendor selection decisions & Bayazit (2006) \\
Contractor selection & Cheng and Li [24] \\
\hline
\end{tabular}

The ANP model is comprised of the clusters of decision criteria and connections among them. The model allows for connections between nodes in a cluster or nodes between clusters as long as there is a relationship between them. The technique offers a more realistic way to model a real-world scenario, by taking into account the relationships that often imminent in decision process. These interactions help capture the complex effects of interplay in human society such as trade-off between economic and social values in contractor selection for BOT project.
The methodology of the ANP is well elucidated in literatures $[24,28,29]$. To measure relative importance of criteria, Professor Saaty has postulated a nine-point priority scale for obtaining judgement matrix, as shown in Table 3.

For $n$ criteria, Saaty's fundamental scale is used to compute pairwise comparison for matrix $\mathrm{A}$, based on the judgement $a_{i j}$, where $a_{j i}=1 / a_{i j}$ (Tab. 4).

From matrix A, judgement $a_{i j}\left(C_{1} / C_{1}-C_{1} / C_{n}\right)$ are single number drawn from fundamental scale, their reciprocal is input for $a_{j i}$. 
Table 3. The fundamental scale.

\begin{tabular}{|c|c|c|}
\hline $\begin{array}{l}\text { Intensity of } \\
\text { importance }\end{array}$ & Definition & Explanation \\
\hline 1 & Equal importance & Two activities contribute equally to the objective \\
\hline 3 & $\begin{array}{l}\text { Moderate importance of one over } \\
\text { another }\end{array}$ & $\begin{array}{l}\text { Experience and judgement slightly favour one } \\
\text { activity over another }\end{array}$ \\
\hline 5 & Essential or strong importance & $\begin{array}{l}\text { Experience and judgement strongly favour } \\
\text { one activity over another }\end{array}$ \\
\hline 7 & Very strong importance & $\begin{array}{l}\text { An activity is favoured, and its dominance } \\
\text { demonstrated in practice }\end{array}$ \\
\hline 9 & Extreme importance & $\begin{array}{l}\text { The evidence favouring one activity over is of the } \\
\text { highest possible order of affirmation }\end{array}$ \\
\hline $2,4,6,8$ & $\begin{array}{l}\text { Intermediate values between the two } \\
\text { adjacent judgements }\end{array}$ & When compromise is needed \\
\hline Reciprocals & \multicolumn{2}{|c|}{$\begin{array}{l}\text { If activity } i \text { has one of the above numbers assigned to it when compared with activity } j \text {, then } j \text { has } \\
\text { the reciprocal value when compared with } i\end{array}$} \\
\hline
\end{tabular}

Source: Adapted from Saaty [29].

Table 4. Pairwise comparison matrix.

\begin{tabular}{|c|c|c|c|c|c|c|}
\hline & & \multicolumn{5}{|l|}{$\mathrm{A}_{j}$} \\
\hline & & $\mathrm{A}_{2}$ & $C_{2} / C_{1}$ & $C_{2} / C_{2}$ & - & - \\
\hline & & - & - & - & - & - \\
\hline & & - & - & - & - & \\
\hline
\end{tabular}

Table 5. Random index.

\begin{tabular}{|c|c|c|c|c|c|c|c|c|c|c|c|c|c|c|c|}
\hline Order & 1 & 2 & 3 & 4 & 5 & 6 & 7 & 8 & 9 & 10 & 11 & 12 & 13 & 14 & 15 \\
\hline $\begin{array}{l}\text { First-order } \\
\text { differences }\end{array}$ & & 0 & 0.52 & 0.37 & 0.22 & 0.14 & 0.10 & 0.05 & 0.05 & 0.04 & 0.03 & 0.02 & 0.02 & 0.02 & 0.01 \\
\hline
\end{tabular}

Source: Saaty [29].

The formula $n(n-1) / 2$ is a guide for the number of comparison in matrix A. The reliability of judgements in the pairwise comparisons is determined by the consistency ratio:

$$
\mathrm{CR}(\mathrm{A})=\frac{\mathrm{CI}(\mathrm{A})}{(\mathrm{RI})}
$$

where $\mathrm{CR}=$ consistency ratio, $\mathrm{CI}=$ consistency index, $\mathrm{RI}=$ random consistency index

To compute a CI of matrix A:

$$
\mathrm{CI}(\mathrm{A})=\frac{\Delta_{\max }-n}{n-1}
$$

where $\left[\lambda_{\max }\right]=$ principal eigenvector, $n=$ number of criteria.
$\mathrm{RI}$ is an experimental value that depends on $n$. Assume $n=9$, as shown in Table 5 , value for $\mathrm{RI}=1.45$.

\section{Research methodology}

Following the preliminary findings on BOT contracts and social challenges in Nigeria, systemic approach [30] was considered the most appropriate technique to design framework for contractor selection. As opposed to unidirectional approach to problem solving, systemic (i.e. closed-loop) structure of decision problem highlights the ideology of reductionist approach where complex processes are broken down into a few component parts in the form of selected sustainability indicators [21]. The approach is applauded to be more effective and efficient in solving messy situation [24,31]. 


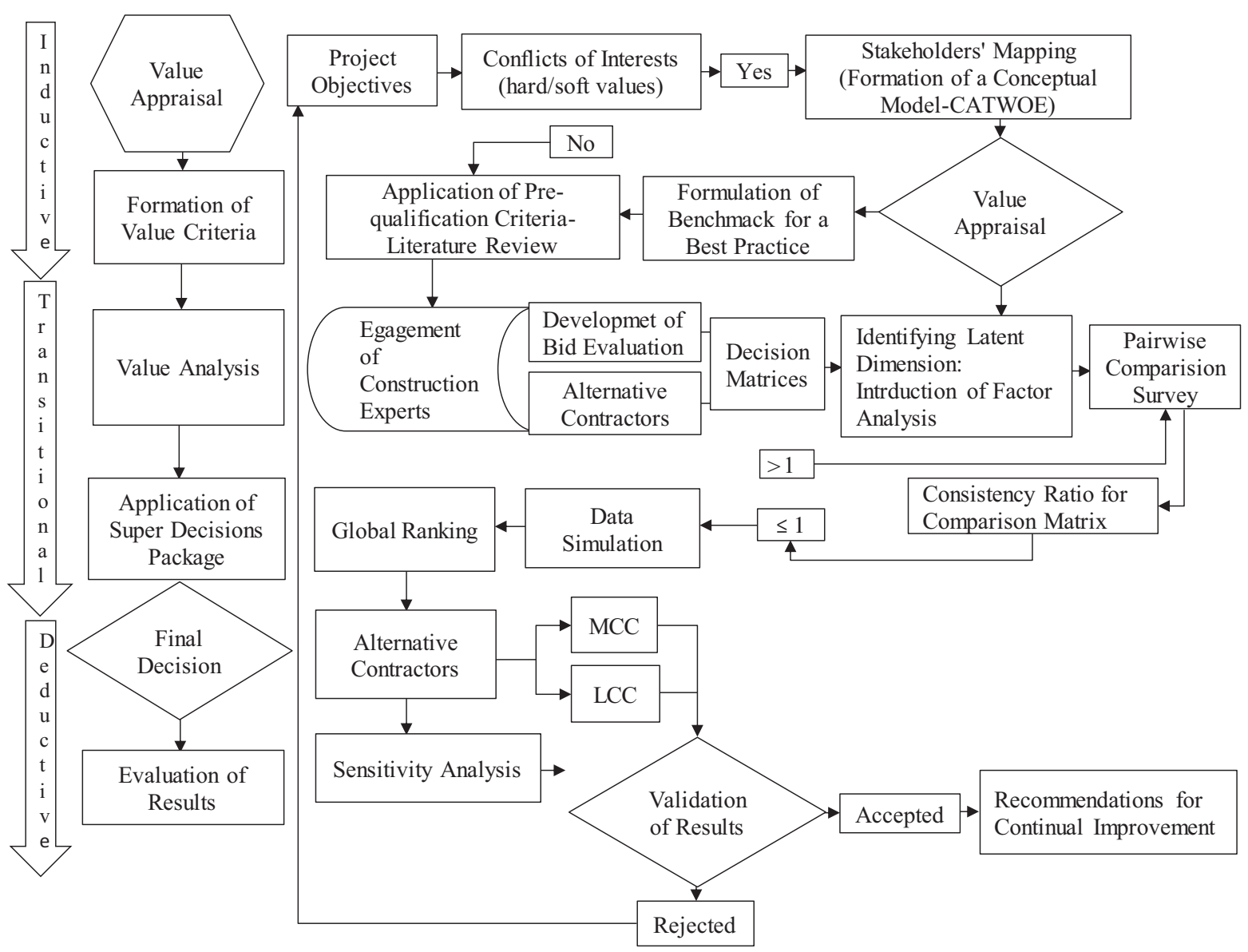

Fig. 2. Proposed SID model for contractor selection.

The proposed SID model constituted the overall research framework. The model, as illustrated in Figure 2 can be simplified into three phases. The inductive phase is the broadest phase of the model. For this study, the goal of contractor selection is to deliver sustainable infrastructure. Objectives will include economic returns on investment, quality infrastructure and social progress, which can be measured in terms of local employment creation and capacity building. Transitional phase involves value analysis and data synthesis. With the support of decision-making panel, decision criteria are structured ad prioritised with the implementation of ANP. Deductive phase is where data results are analysed, reviewed and implemented.

Principal methods of data collection applied were literature review, government publications and web-based questionnaire survey. Following the in-depth literature review on contractor selection criteria, a total of 55 selection criteria were identified and designed to a questionnaire. The first-round survey involved the application of random and snowball samplings (non-probability sampling strategies) [32], using web-based tool. Web-based questionnaire survey technique is a well-tested tool among researchers' in-built environment. The growing popularity of web-based survey could be attributed to its overall costeffectiveness and time saving when it is compared with other data collection (interview, survey, focus group and workshop) techniques. The technique is invaluable in reaching hidden population and handy to cover a wider distribution with automated data entry. Though probability sampling technique of data collection is easy to validate due to insignificant sampling error, the major challenge with probability sampling, as evident in this study, arises when sampling frame is not available [32].

The questionnaire was designed in two sections. The first section comprised of general background information of a respondent. It aimed at gaining information on discipline, field of work, education level and current position, nature of industry and awareness on BOT contract. In section two, respondents were asked to rank the importance of selection criteria on a five-point Likert scale, where 5 represents "very important" and 1 represents "not important".

\section{Results and discussion}

A total of 143 questionnaire feedbacks was analysed with the IBM SPSS Statistics 22. The descriptive analysis revealed the composition of respondents as $15 \%$ education sector, $18 \%$ government agency, $38 \%$ local construction company, $12 \%$ local manufacturing company and $17 \%$ foreign construction company. The research findings further affirmed the claim that is considerable quantity 
Table 6. KMO and Bartlett's test.

\begin{tabular}{llc}
\hline $\begin{array}{l}\text { Kaiser-Meyer-Oikin measure } \\
\text { of sampling adequacy }\end{array}$ & \multicolumn{1}{l}{$\begin{array}{l}\text { Approx. } \\
\text { chi-square }\end{array}$} & 397.571 \\
Bartlett's test of sphericity & df & 120 \\
& Sig. & .000 \\
\hline
\end{tabular}

Source: Analysis of surveyed data, 2017.
Table 8. Prioritisation of elements between clusters.

\begin{tabular}{|c|c|c|c|}
\hline $\begin{array}{l}\text { Which has a } \\
\text { greater influence? }\end{array}$ & M1 & M2 & $\begin{array}{l}\text { Equal } \\
\text { importance }\end{array}$ \\
\hline
\end{tabular}

Compare the following elements in the cluster Environment according to their importance upon element M10, Financial security, in the cluster Asset.

Source: Adapted from Aragones-Beltran et al. [28].

Table 7. Component matrix.

\begin{tabular}{|c|c|c|c|c|c|}
\hline & \multicolumn{5}{|c|}{ Component } \\
\hline & 1 & 2 & 3 & 4 & 5 \\
\hline Adequate training & & & .761 & & \\
\hline Cooperation with workers' union & .717 & & & & \\
\hline Quality of human resources & & .896 & & & \\
\hline Availability of equipment & & .878 & & & \\
\hline Employment creation for locals & .695 & & & & \\
\hline Waste management & & & & & .664 \\
\hline Working capitals & & .650 & & & \\
\hline Proposed construction methods & & & .849 & & \\
\hline Local material sourcing & & & & & .500 \\
\hline Relationship with insurance companies & & & & -.668 & \\
\hline Contractor social responsibility initiatives & .648 & & & & \\
\hline Employee well-being & -.489 & & & & \\
\hline Site safety records & & & & .486 & \\
\hline Experience in project of similar nature & & & -.792 & & \\
\hline Project management experience & & & .475 & & \\
\hline Claims and dispute history & & & & .430 & \\
\hline
\end{tabular}

Extraction method: principal component analysis; rotation method: Varimax and Kaiser normalization. Five components extracted. Source: Analysis of surveyed data, 2017.

of local contractor in Nigeria, although small in size and incapable to undertake complex civil engineering and building projects. The fewer MCC are found to execute over $90 \%$ of total value of construction contract [16].

To verify the suitability of data set for factor analysis, the Kaiser-Meyer-Oikin (KMO) and Bartlett's test of sphericity were carried out to scrutinise the sampling suitability. The techniques are commonly used in the literatures [33]. The KMO is the ratio of the squared correlation between variables to the squared partial correlation between variables. The statistics for KMO vary between 0 and 1 . A value that is close to 1 indicates that patterns of correlations are relatively compact and so factor analysis should yield distinct and reliable factors. A recommended minimum value for $\mathrm{KMO}$ is 0.50 [33]. For Bartlett's test, maximum value should be 0.05 [33].

For the data set in this study, as shown in Table 6, KMO value is 0.519 and it validates the suitability of the data for factor analysis.

\subsection{Data reduction}

Among the 55 data sets used for the study, there was an evidence of significant correlation among predictor variables based on exploratory factor analysis correlation matrix. Furthermore, the determinate of the correlation matrix being $4.86 \mathrm{E}-006$ (which is less than 0.00001) also strengthens the evidence and problem of multicollinearity for the data set. This problem was resolved by eliminating variables for which most of the values are greater than 0.05 and correlation greater than 0.9. More importantly, principal component analysis of factor analysis supported data reduction for the second-round survey that involved the implementation of ANP. By doing so, inherent challenges of conducting many pairwise comparison are minimised.

The factors extraction (in Tab. 7) were modified to clusters based on their lurking dimensions. Two broad classification of contractors identified from literature 


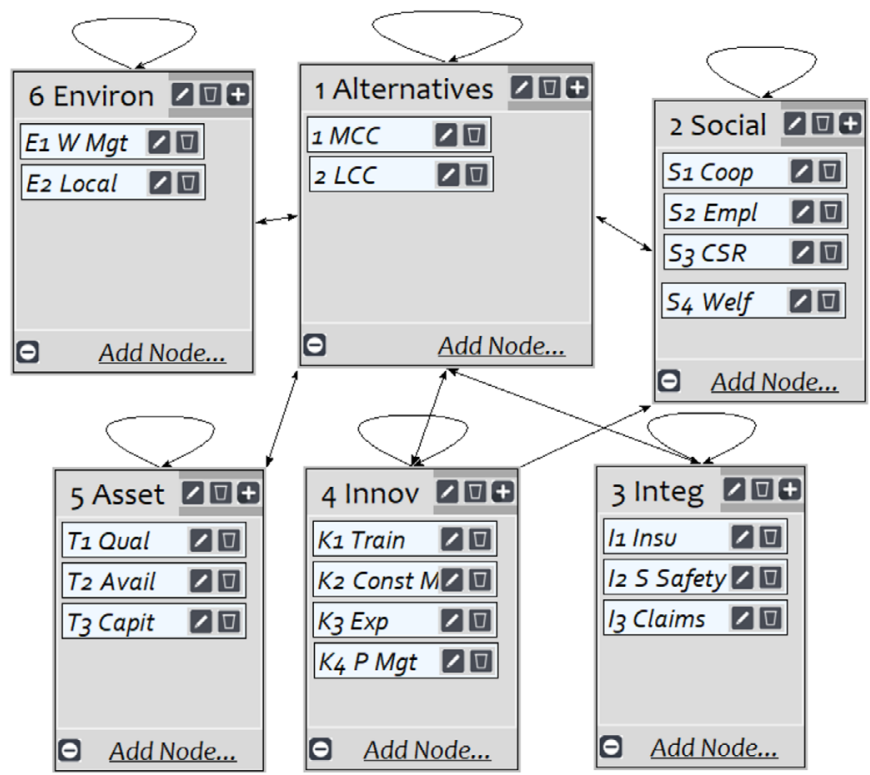

Fig. 3. ANP-based contractor selection model in Super Decisions. E1 = waste management, E2 = local material sourcing, L1= relationship with insurance companies, L2 = site safety records, L3 = claims and disputes history, $\mathrm{K} 1=$ adequate training for operating process, $\mathrm{K} 2=$ proposed construction methods, $\mathrm{K} 3=$ experience in project of similar nature, $\mathrm{K} 4=$ project management experience, $\mathrm{S} 1=$ cooperation with workers' union, $\mathrm{S} 2=$ employment creation for locals, S3 = contractor social responsibility initiatives, $\mathrm{S} 4=$ employee welfare, $\mathrm{T} 1=$ quality of human resources, T2 = availability of equipment, T3=working capital, Environ $=$ environmental conservation, Social $=$ social integration, Asset $=$ asset, Innov $=$ managerial skills and innovation, Integ $=$ reputation and integrity.

\begin{tabular}{|c|c|c|}
\hline Name & $\longdiv { \text { Normalized by Cluster } }$ & $\longdiv { \text { Limiting } }$ \\
\hline $1 \mathrm{MCC}$ & 0.63764 & 0.154303 \\
\hline $2 \mathrm{LCC}$ & 0.36236 & 0.087687 \\
\hline S1 Coop & 0.17365 & 0.029856 \\
\hline $\mathrm{S} 2 \mathrm{Empl}$ & 0.36714 & 0.063123 \\
\hline S3 CSR & 0.11161 & 0.019190 \\
\hline S4 Welf & 0.34760 & 0.059763 \\
\hline I1 Insu & 0.33614 & 0.028712 \\
\hline 12 S Safety & 0.41345 & 0.035315 \\
\hline I3 Claims & 0.25041 & 0.021389 \\
\hline K1 Train & 0.18338 & 0.017986 \\
\hline K2 Const M & 0.28895 & 0.028341 \\
\hline K3 Exp & 0.32433 & 0.031811 \\
\hline K4 P Mgt & 0.20334 & 0.019944 \\
\hline T1 Qual & 0.27466 & 0.083542 \\
\hline T2 Avail & 0.26002 & 0.079089 \\
\hline T3 Capit & 0.46533 & 0.141538 \\
\hline E1 W Mgt & 0.49814 & 0.049023 \\
\hline E2 Local & 0.50186 & 0.049389 \\
\hline
\end{tabular}

Fig. 4. Nodes priorities.

reviews, based on the ownership [16], are branded as MCC and local construction companies (LCC) based on the ownership. The overall clusters and their nodes were modelled to pairwise comparison matrices to facilitate second-round questionnaire survey (Tab. 8).

Table 9. Limit matrix.

1 MCC 2 LCC S1 Coop S2 Empl S3CSR S4 Welf I1 Insu I2 SSafety I3 Claims K1 Train K2 Const K3 Exp K4 PMgt T1 Qual T2 Avail T3 Capit E1 W Mgt E2 Local

1 Alt 1 MCC $\quad 0.1543030 .1543030 .1543030 .1543030 .1543030 .1543030 .1543030 .154303 \quad 0.1543030 .1543030 .1543030 .1543030 .1543030 .1543030 .1543030 .1543030 .1543030 .154303$ LLCC $\quad 0.0876870 .0876870 .0876870 .0876870 .0876870 .0876870 .0876870 .087687 \quad 0.0876870 .0876870 .0876870 .0876870 .0876870 .0876870 .0876870 .0876870 .0876870 .087687$

2Soc S1 Coop $\quad 0.0298560 .0298560 .0298560 .0298560 .0298560 .0298560 .0298560 .0298560 .0298560 .0298560 .0298560 .0298560 .0298560 .0298560 .0298560 .0298560 .0298560 .029856$

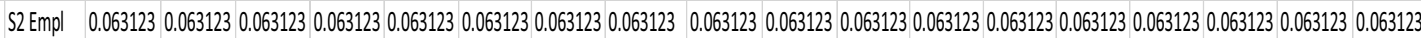
S3 CSR $\quad 0.019190 \quad 0.0191900 .0191900 .0191900 .0191900 .0191900 .0191900 .019190 \quad 0.0191900 .0191900 .0191900 .0191900 .0191900 .0191900 .0191900 .0191900 .0191900 .019190$ S4 Welf $\quad 0.0597630 .0597630 .0597630 .0597630 .0597630 .0597630 .0597630 .059763 \quad 0.0597630 .0597630 .0597630 .0597630 .0597630 .0597630 .0597630 .0597630 .0597630 .059763$

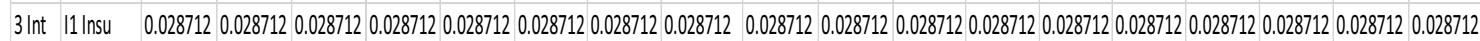

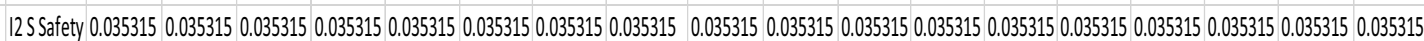
I3 Claims $\quad 0.0213890 .0213890 .0213890 .0213890 .0213890 .0213890 .0213890 .0213890 .0213890 .0213890 .0213890 .0213890 .0213890 .0213890 .0213890 .0213890 .0213890 .021389$

4 Inn K1 Train 0.0179860 .0179860 .0179860 .0179860 .0179860 .0179860 .0179860 .0179860 .0179860 .0179860 .0179860 .0179860 .0179860 .0179860 .0179860 .0179860 .0179860 .017986

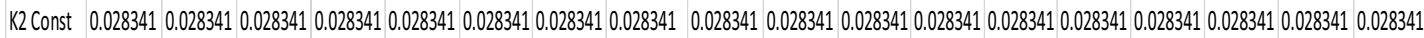
K3 Exp 0.0318110 .0318110 .0318110 .0318110 .0318110 .0318110 .0318110 .0318110 .0318110 .0318110 .0318110 .0318110 .0318110 .0318110 .0318110 .0318110 .0318110 .031811 K4 P Mgt $\quad 0.0199440 .0199440 .0199440 .0199440 .0199440 .0199440 .0199440 .0199440 .0199440 .0199440 .0199440 .0199440 .0199440 .0199440 .0199440 .0199440 .0199440 .019944$

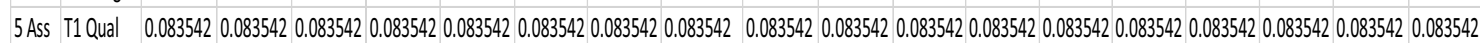
T2 Avail $\quad 0.0790890 .0790890 .0790890 .0790890 .0790890 .0790890 .0790890 .0790890 .0790890 .0790890 .0790890 .0790890 .0790890 .0790890 .0790890 .0790890 .0790890 .079089$ T3 Capit 0.1415380 .1415380 .1415380 .1415380 .1415380 .1415380 .1415380 .1415380 .1415380 .1415380 .1415380 .1415380 .1415380 .1415380 .1415380 .1415380 .1415380 .141538

6Env E1 W Mgt $0.049023 \quad 0.0490230 .0490230 .0490230 .0490230 .0490230 .0490230 .0490230 .0490230 .0490230 .0490230 .0490230 .0490230 .0490230 .0490230 .0490230 .0490230 .049023$ E2 Local $\quad 0.0493890 .0493890 .0493890 .0493890 .0493890 .0493890 .0493890 .0493890 .0493890 .0493890 .0493890 .0493890 .0493890 .0493890 .0493890 .0493890 .0493890 .049389$, 


\begin{tabular}{|l|l|l|l|l|}
\hline \multicolumn{3}{l}{$\begin{array}{l}\text { Here are the overall synthesized priorities for the } \\
\text { alternatives. You synthesized from the network Main } \\
\text { Network: Final Solution.sdmod: ratings }\end{array}$} \\
\hline Name & Graphic & Ideals & Normals & Raw \\
\hline \hline 1 MCC & & 1.000000 & 0.637643 & 0.154303 \\
\hline \hline 2 LCC & & 0.568275 & 0.362357 & 0.087687 \\
\hline
\end{tabular}

Fig. 5. Final solution.

As reported by Aragones-Beltran et al. [28], it is critical that decision makers have good knowledge of the decision problem. Purposeful sampling method was explored [34] to select construction experts who participated in pairwise comparison survey. Using social media and networking, 15 experts in the Nigerian construction sector were precontacted and they were briefed about the ongoing research. Seven people expressed their commitment to participate in the pairwise comparison exercise. They comprised of two facility managers, three quantity surveyors, one civil engineer and one construction manager. The entire team have achieved chartered status in their respective construction-related disciplines. Also, they have been actively engaged in construction project procurement.

\subsection{Calculating the priorities between elements of the cluster}

Priorities were computed between elements of the same cluster, and between clusters as long there was a relationship. The Super Decision (trial version was used for analysis of the survey results. The purpose is to determine which criterion is more influential and to what extent among the elements of a cluster. The software obtained the inconsistency index of each of the DM results.

The screenshot of the Super Decisions gives relationship information about decision nodes. A loop on a cluster indicates that at least two nodes are linked within the cluster (inner dependence). An arrow indicates that relation exist between nodes of at least two clusters. The source of the arrow is the cluster that contains a "parent node". The "sink cluster" contains "children nodes".

\subsection{Computing unweighted, weighted and limit supermatrices}

After the pair comparisons of nodes and the calculation eigenvectors have been completed, the software compute results for unweighted supermatrix. As shown in Figure 3, there are influences among elements of different clusters. The unweighted matrix is, therefore, non-stochastic by columns as the sum will be greater than 1 . To make supermatrix column stochastic, clusters must be compared to establish their relative importance and use it to weigh the supermatrix [29]. After clusters' priorities have been established, elements in each of the cluster were multiplied by the cluster priority, which result in weighted supermatrix. The weighted supermatrix was then raised to limiting powers until the weights converged and remained stable. At this point, limit supermatrix was obtained.

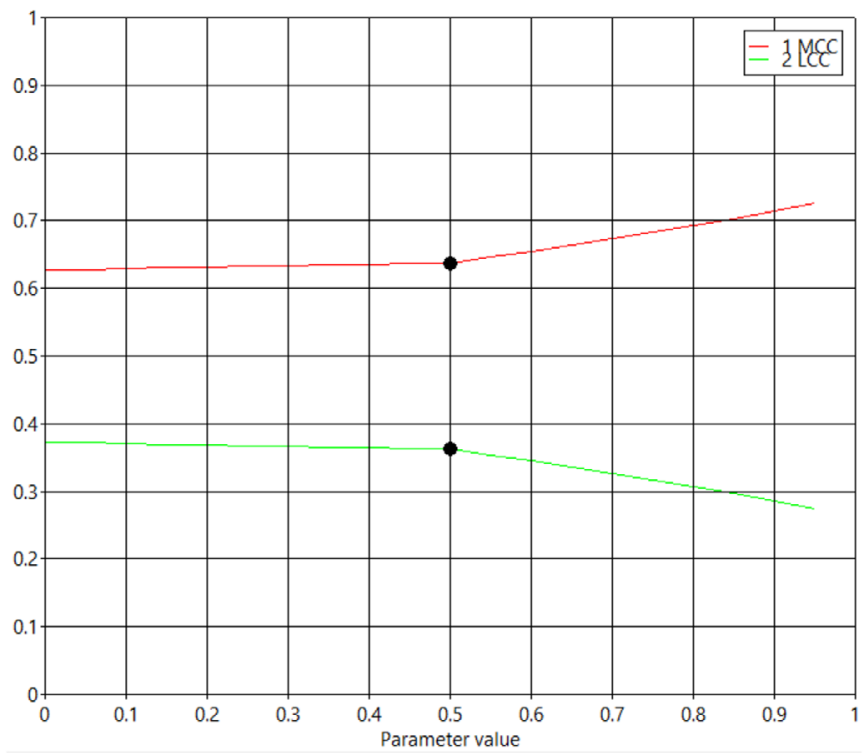

Fig. 6. Sensitivity analysis for site safety.

Table 9 compiles the results obtained after the weighted supermatrix was raised to limiting powers until the weights converged and remained stable.

Data in Figure 4 contains "limiting" and "normalised by cluster" columns. "Limiting" column includes data obtained directly from limit matrix (Tab. 9).

Figure 4 shows nodes priorities. "Normalised by cluster" column compiles the normalised values of the limit matrix, and it can be interpreted as follows:

The value of nodes represents their values after sum of nodes in each cluster has been normalised, i.e. sum to 1 $(100 \%)$. For instance, in "social skills" cluster, there are four nodes (S1, S2, S3 and S4), with values of $\mathrm{S} 1=0.17365$, $\mathrm{S} 2=0.36714, \mathrm{~S} 3=0.11161$ and $\mathrm{S} 4=0.34760$. This means by percentage of the priorities of the four nodes in "social skills" cluster, $\mathrm{S} 1=17 \%, \quad \mathrm{~S} 2=37 \%, \quad \mathrm{~S} 3=11 \% \quad$ and $\mathrm{S} 4=35 \%$, respectively.

The results for the priorities of the alternatives, the number shown in the "raw column" (Fig. 5), are directly from the limit matrix.

The values were normalised to obtain the priorities in the "normal column", which added up to 1 . The priorities in the "ideal column" were obtained by dividing each raw number by the largest, 0.637643 , which resulted in the "ideal" alternative having a value of 1 .

\subsection{Sensitivity analysis}

Sensitivity analysis, or what-if analysis, may provide a useful insight into the alternatives being described based on a set of criteria. The approach involves observing relative impacts of slight modification of the priorities of elements of the network on the overall outcome.

The usefulness of the analysis is to inform on key criteria that require special attention due to higher improvement being achieved from a slight improvement. The results obtained from "node priorities" in Figure 5 were subjected to minor manipulations. Figure 6 is the 
sensitivity results for L2 (site safety). The result implies that the more the priority given to site safety, the better to engage with MCC for better performance.

\section{Conclusions}

In this paper, SID model has been proposed as an innovative framework for contractor selection that promotes sustainable infrastructure delivery. ANP has been incorporated at the deductive phase of the model for data synthesis. Being a multicriteria decision-making technique, ANP resolves the setbacks that are often associated with the application of linear arithmetic methods in evaluating contractor that deliver sustainable infrastructure.

The paper focussed on extensive literature reviews and identified 16 critical criteria that support contractor selection that promote SID. Based on their lurking dimensions, they were grouped into five decision clusters: environmental conservation, social integration, asset, managerial skills and innovation and reputation and integrity. To demonstrate the effectiveness and efficiency of the proposed SID model, paired comparison questionnaire survey was completed with the support construction experts. The criteria were computed for their relative importance for the selection of contractors for BOT projects.

The overall results predicted that $\mathrm{MCC}$ would perform better than LCC in SID, although they were not absolute. While MCC performed better on economic and environmental terms, inclusion of local skills in supply chain and local sourcing of resources remained key divers of social development. Okonjo-Iweala and Osafo-Kwaako [17] noted that perpetual poverty is due to the achievements of the economic reforms that fail to transform to welfare improvements for citizens. The final results revealed that applied 16 criteria differ in their sensitivity on achieving SD. DU-Plessi [1] reiterated the need for the creation of effective and efficient local construction sector to achieve SD. Though MCC performed better on "social responsibility initiatives", it is a self-regulated mechanism; hence, evaluation of impacts of CSR on human development in DC remains a mammoth task. Extensive studies have proved there is no consensus view among researchers on the contributions of CSR towards environmental management and employment opportunities. From the findings, safety is very critical, and it influences overall project performance. Due to poor safety records of LCC [16], it requires adequate training. To improve on the performance of local contractors, they must gain experience in projects of similar nature. Training becomes vital. Though local skills cannot effectively manage leading role, they should be structured to the production process. Ofori [6] highlights key indicators for measuring construction development in developing countries, and they include the number of workers skill tested, number of workers trained and the number of supervisors trained. These would show that whole life costs of procured constructed facilities are well evaluated to achieve value for money (BS 8903:2010).

Compared with South Africa [17], much still needs to be done in infrastructure delivery to create improve microeconomic environment. The reliance largely on oil export earnings makes the Nigeria's economy ranked among the most volatile in the world [17]. The macroeconomic instability creates non-competitive environment for industrial production [11] and drive outsourcing a preferred option by the MCC.

Regarding the detriment of paired comparison survey that is often voluminous, common in implementation of ANP, decision makers acknowledge that voluminous questions were involved in the survey, although they confirmed that the burden was lessened due to their experience and skills. They further commended the initiation of the factor analysis to eliminate less important criteria, which have significantly reduced the number of required matrices.

Overall, the proposed SID model has demonstrated the need for a shift in the modus operandi of the MDAs from unidirectional to systemic selection techniques. It clearly demonstrated the appropriateness of the ANP to predict the contractor that delivers sustainable infrastructure.

\section{References}

1. C. Du-Plessis, A strategic framework for sustainable construction in developing countries, Constr. Manage. Econ. 25, 67 (2007)

2. P.F. Kaming, P.O. Olomolaiye, P. Corbett, F.C. Harris, A framework for the strategic development of the construction industry in developing countries, Build. Res. Inform. 22, 325 (1994)

3. J.S. Omotola, Combating poverty for sustainable human development in Nigeria: the continuing struggle, J. Poverty 12, 496 (2008)

4. O. Moyo, Poverty and globalization in Africa, J. Int. Comp. Social Welf. 18, 51 (2002)

5. O.K. Babatunde, S.P., Low Chinese construction firms in the Nigerian construction industry, Habitat Int. 40, 18 (2013)

6. G. Ofori, Indicators for measuring construction industry development in developing countries, Build. Res. Inform. 29, 40 (2001)

7. B.I. Ajufo, Challenges of youth unemployment in Nigeria: effective career guidance as a panacea, Afr. Res. J. 7, 307 (2013)

8. Federal Government of Nigeria, Nigeria's Path to Sustainable Development through Green Economy, Country Report to the Rio + 20 Summit, 2012. Available at https:// sustainabledevelopment.un.org/content/documents/ 1023nigerianationalreport.pdf

9. A. Opawole, G.O. Jagboro, Benchmarking parties' obligations in the execution of concession-based PPP projects in Nigeria, J. Place Manage. Dev. 9, 27 (2016)

10. A. Walraven, B. de Vries, From demand driven contractor selection towards value driven contractor selection, Constr. Manage. Econ. 27, 597 (2009)

11. I. Taylor, China's relations with Nigeria, Round Table, 96, 631 (2007)

12. O. Oduyemi, M.I. Okoroh, O.S. Fajana, O. Arowosafe, The need for economic performance measures for life cycle costing of sustainable commercial office buildings, J. Facil. Manage. 16, 54 (2018)

13. P.O. Akadiri, Understanding barriers affecting the selection of sustainable materials in building projects, J. Build. Eng. 4, $86(2015)$ 
14. J. Egan, Rethinking construction, Egan Report, Department of the Environment, Transport and the Regions, London, Publications Sale Centre, Rotherham, UK, 1998

15. D.R. Ogunsemi, G.O. Jagboro, Time-cost model for building projects in Nigeria, Constr. Manage. Econ. 24, 253 (2006)

16. G.I. Idoro, Influence of quality performance on clients' patronage of indigenous and expatriate construction contractors in Nigeria, J. Civil Eng. Manage. 16, 65 (2010)

17. N. Okonjo-Iweala, P. Osafo-Kwaako, Nigeria's economic reforms: progress and challenges, Brookings Global Economy and Development, Working paper No. 6, 2007

18. C.S. Ayomike, B.C. Okeke, The Nigerian local content act and its implication on technical and vocational education and training (TVET) and the nation's economy, Int. J. Educ. Learn. Dev. 3, 26 (2015)

19. ICRC, Nigeria Public-Private Partnerships Manual, 2012. Available at http://ppptoolkit.icrc.gov.ng/introduction-toppp/ (accessed 27-01-2014)

20. K.F. Al-Azemi, R. Bhamra, A.F.M., Salman risk management framework for build, operate and transfer (BOT) projects in Kuwait, J. Civil Eng. Manage. 20, 415 (2014)

21. N.A. Patil, D. Tharun, B. Laishram, Infrastructure development through PPPs in India: criteria for sustainability assessment, J. Environ. Plan. Manage. 59, 708 (2016)

22. O. Arowosafe, B. Ceranic, A. Dean, Construction costs and value management: study of multinational practices in Nigeria, in: COBRA 2015 RICS International Research Conference, Sydney, Australia, 8-10 July 2015

23. A. Enshassi, S. Mohamed, Z. Modough, Contractors' selection criteria: opinions of Palestinian construction professionals, Int. J. Constr. Manag. 13, 19 (2013)

24. E.W.L. Cheng, H. Li, Contractor selection using the analytic network process, Constr. Manage. Econ. 22, 1021 (2004)
25. E. Palaneeswaran, M. Kumaraswamy, T. Ng, Targeting optimum value in public sector projects through "best value"focused contractor selection, Eng. Constr. Arch. Manage. 10, 418 (2003)

26. E. Palaneeswaran, M.M. Kumaraswamy, Benchmarking contractor selection practices in public-sector construction: a proposed model, Eng. Constr. Arch. Manage. 7, 285 (2000)

27. C.H. Wong, G.D. Holt, P.A. Cooper, Lowest price or value? Investigation of UK construction clients' tender selection process, Constr. Manage. Econ. 18, 767 (2000)

28. P. Aragones-Beltran, J.P. Pastor-Ferrando, F. GarciaGarcia, A. Pascual-Agullo, An analytic network process approach for siting a municipal solid waste plant in the metropolitan area of Valencia (Spain), J. Environ. Manage. 91, 1071 (2010)

29. T.L. Saaty, Decision making with the analytic hierarchy process. Int. J. Services Sci. 1, 83 (2008)

30. E. Chinyio, A. Akintoye, Practical approaches for engaging stakeholders: findings from the UK, Constr. Manage. Econ. 26, 591 (2008)

31. A. Mardani, A. Jusoh, K.M.D. Nor, Z. Khalifah, N. Zakwan, A. Valipour, Multiple criteria decision-making techniques and their applications: a review of the literature from2000 to 2014, Econ. Res. 28, 516 (2015)

32. S. Brammer, H. Walker, Sustainable procurement in the public sector: an international comparative study, Int. J. Oper. Prod. Manage. 31, 452 (2011)

33. L.O. Oyedele, K.W. Tham, Clients' assessment of architects' performance in building delivery process: evidence from Nigeria, Build. Environ. 42, 2090 (2007)

34. N.Z. Abidin, C.L. Pasquire, Delivering sustainability through value management concept and performance overview, Eng. Constr. Arch. Manage. 12, 168 (2005)

Cite this article as: O. Arowosafe, O. Oduyemi, B. Ceranic and A. Dean: Sustainable infrastructure delivery in Nigeria: implementation of the analytic network process for contractor selection. Sust. Build. 3, 5 (2018). 